\title{
Knowledge, attitudes and practices regarding rabies among community members: a cross-sectional study in Songan Village, Bali, Indonesia
}

\section{Paulus Mario Christopher ${ }^{1}$, Cucunawangsih Cucunawangsih ${ }^{2}$, Anak Agung Gde Bagus Adidharma ${ }^{1}$, I Putu Desna Kesuma Putra ${ }^{1}$, Dewa Gede Sentana Putra ${ }^{1}$}

${ }^{1}$ Public Health Centre of Kintamani V, Songan, Bali, Indonesia

${ }^{2}$ Department of Microbiology, Faculty of Medicine, Pelita Harapan University, Banten, Indonesia

\begin{abstract}
Background: Rabies is a preventable yet endemic zoonotic disease caused by a neurotrophic virus, a member of Rhabdoviridae family. Rabies remains a public health threat in Indonesia, specifically Bali Province. The present study aimed to understand the knowledge, attitudes and practices (KAP) regarding rabies among community members in Songan Village, Bali, Indonesia.

Materials and methods: We conducted a cross-sectional survey using a structured questionnaire among 175 community members residing in the administrative area of public health centre of Kintamani $V$ in Songan Village of Bangli District, from December 2019 to February 2020. Statistical analyses were performed with SPSS software, version 21.

Results: Of the 175 community members, 53 (30.3\%) owned a dog. Majority of the respondents were Hindu (98.8\%), female (56.0\%), aged $\geq 29$ years old (54.9\%), with an educational background of higher secondary (28.6\%), residing in Songan A and B residential village (86.9\%), working as farmers (50.9\%), with the level of income less than district minimum wage (71.4\%). The KAP scores mean \pm standard deviation were $6.93 \pm 1.83$ and $8.04 \pm 1.07$ (out of 10), respectively. Multivariable logistic regression models were constructed and the KAP of the community members was found to be significantly influenced by occupation ( $p$-value $<0.05$ ).

Conclusions: Albeit community members demonstrated some level of KAP regarding rabies, overall, this study revealed critical gaps in their fundamental knowledge of rabies, the prevention in dogs, and the local rules and regulations concerning rabies. In accordance with One Health Approach, further enforcement on the collaborative efforts for comprehensive education programmes, scheduled mass vaccination for dogs, and promotion for healthier attitudes and practices are recommended.
\end{abstract}

(Int Marit Health 2021; 72, 1: 26-35)

Key words: knowledge, attitude, practice, rabies, Bali

\section{INTRODUCTION}

Rabies, a zoonotic disease, is caused by a neurotrophic virus member of the Lyssavirus genus and Rhabdoviridae family. This disease is mostly spread through the bite of an infected dog [1]. Globally, domestic dogs contributed over $95 \%$ of approximate 59,000 human rabies deaths annually in more than 150 countries, with the highest burden of disease in parts of Asia and Africa [2]. Regionally, in South-East Asia, over 3 billion people were affected with dog rabies and more than 30,000 deaths occur annually with a mortality rate of one per 15 minutes, and nationally, in Indonesia, only nine out of 34 provinces are rabies-free province [3, 4].

Dr. Paulus Mario Christopher, Public Health Centre of Kintamani V, Songan, Bali, Indonesia, e-mail: paulusmarioc@gmail.com 
According to the Ministry of Health of the Republic of Indonesia, within 5 years (2011-2015), the rate of dog bite cases per year was 78,413 cases with 65,534 cases receiving the anti-rabies vaccine [4]. In 2019, Bali Province ranked first for dog bite cases with 38,187 cases, followed by Nusa Tenggara Timur Province with 13,599 cases [5]. Bangli was recorded as one of Bali Province districts with high dog bite cases [6].

In Indonesia, the Ministry of Health has established rabies elimination strategy by 2020 through integrated strategy using the One Health Approach engaging multiple stakeholders with advocation and socialisation, mass immunisation and population management towards dogs, and pre-and post-exposure prophylaxis with the anti-rabies vaccine as several of the listed strategies. This strategy is in line with the global "Zero by 30 ", a global action to attain zero human deaths from dog-mediated rabies by 2030, which is supported by the World Health Organization (WHO), World Organization for Animal Health (OIE), Food and Agriculture Organization of the United Nations (FAO), and Global Alliance for Rabies Control (GARC) [7]. Following this strategy, community members serving as one of the stakeholders, further assessing rabies understanding, were pivotal, and one of the methods that can be used to evaluate is through knowledge, attitudes and practices (KAP) studies. Nevertheless, in Indonesia, only a few reports have been published and data concerning KAP in Bali were limited or not made readily accessible. To address this, we developed this research to assess knowledge, attitudes and practices towards rabies in Songan Village of Bangli District, Bali Province, Indonesia.

\section{PARTICIPANTS}

The present study adopted a purposive cross-sectional design with the enrolment of 175 community members presenting to the public health centre (PHC) of Kintamani V from December 2019 to February 2020. The PHC of Kintamani $V$ includes 35 banjars (sub-villages) and animals suspected of rabies (free-roaming dogs [FRDs], cats, monkeys, and bats) were spread throughout the banjars. Therefore, all the community members were a population at risk for rabies infection.

The sample size was calculated using Cochran's sample size formula for categorical data [8]. Allowing a confidence interval $(\mathrm{Cl})$ and a margin of error of $95 \%$ and $10 \%$, respectively, the minimum sample size $(\mathrm{N})$ of community members required for this study was 96 community members.

$$
\mathrm{N}=\frac{\mathrm{Z} \alpha^{2} \mathrm{PQ}}{\mathrm{d}^{2}}=\frac{(1.96)^{2}(0.5)(0.5)}{(0.1)^{2}}=96
$$

The study's inclusion criteria were: 1) community member who resided and were recorded as community members in PHC of Kintamani V ( $\geq 17$ years of age), 2) communicative, and 3) agreed to participate in the study, while the exclusion criteria were 1) community members who do not reside and are not recorded as community members in PHC of Kintamani V.

\section{MATERIALS AND METHODS STUDY AREA}

The study was carried out in the PHC of Kintamani V in Songan Village of Bangli District, Bali Province, Indonesia. Songan Village $(-8.230699,115.407730)$ is approximately $40 \mathrm{~km}$ north of Bangli district and $80 \mathrm{~km}$ North-East of Denpasar, capital of Bali Province. PHC of Kintamani V provides a range of health services to the population living in the area of Songan (Songan A and B) Village, Pinggan Village, and Belandingan Village (approximately 3,400 households with 22,000 people in 2017) and is the only centre offering post-exposure prophylaxis (PEP) for humans bitten by animals suspected of rabies in and around this area. No rabies awareness campaign or dog population control measures had been conducted recently in the past year in the area before this survey.

\section{QUESTIONNAIRE DESIGN}

The knowledge, attitudes and practices (KAP) study were constructed to assess; 1) the awareness and knowledge about rabies, 2) the attitude and health-seeking practice regarding rabies, and 3) the attitude and practice which may have led to the village's persistence of the disease. The structured questionnaire consisted of closed questions on: 1) sociodemographic data (gender, age, religion, educational status, occupation, and income levels); 2) general questions regarding awareness about rabies, attitudes and practices towards dogs, and local rules and regulations concerning rabies; 3) knowledge of rabies (ten questions); and 4) attitudes and practices towards rabies (ten questions). The questionnaire's content validity was demonstrated since the questionnaire was developed based on expert consensus and international guidelines.

The respondents were orally informed about the study's purpose, emphasizing voluntary participation, confidentiality, and informed written consent was obtained prior to the interview. The questions were read out to the respondents in the local language (Bahasa Indonesia) by the interviewer and their answers were recorded in English.

\section{ETHICAL CONSIDERATIONS}

The study was reviewed and approved by the Ethics Committee of the Faculty of Medicine, Pelita Harapan University (Ref: 133/K-LKJ/ETIK/III/2020). The study was cleared by the Dinas Penanaman Modal dan Pelayanan Terpadu Satu Pintu, the provincial government of Bali Province and the district government of Bangli (Ref: 070/1106/IZIN-C/DISPMPT). 


\section{DATA MANAGEMENT AND ANALYSIS}

The data collected from the questionnaires were entered into Excel files (Microsoft Excel, Microsoft Corp. Redmond, WA, USA). Descriptive and inferential analyses were performed. Statistical analyses were performed using Statistical Package for Social Sciences (SPSS) Statistics Version 21.0 (IBM Corp., Released 2012, Armonk, NY, USA). For analytical purposes, the respondents were dichotomised into two age groups based on the median age. The educational background was categorised into three divisions: 1) no formal education, 2) less than or equal to national basic level (1-9), 3) more than national basic level $(\geq 10)$. Occupation was also categorised into three divisions: 1) not working, 2) blue-collar/manual labour workers (farmer, labourer, fisherman, and entrepreneur), and 3) white-collar worker/administrative workers (employee and civil servant).

The respondents were categorised as having adequate or inadequate knowledge of rabies and positive or negative attitudes and practices regarding rabies based on the median score to the responses to the questions pertaining to the questionnaire's relevant sections. Potential factors associated with knowledge, attitudes and practice scores were identified using chi-square $\left(\chi^{2}\right)$ tests of associations.

Multivariable logistic regression analyses were conducted for each outcome variable, namely knowledge, attitudes and practices regarding rabies. This was done to understand the associations of outcome variables with the respondents' characteristics. Results that were statistically significant at $p$-value of $\leq 0.25$ were then offered to multivariable logistic regression models. Variables with p-value of $<0.05$ were retained in the final model. The Hosmer-Lemeshow test assessed the model goodnessof-fit. The design, setting, analyses, and reporting of this study adhered to the STROBE guidelines for cross-sectional studies in epidemiology (Supplementary File 1 - see journal website) [9].

\section{RESULTS \\ RESPONDENT'S CHARACTERISTICS AND AWARENESS OF RABIES}

A total of 175 responses were collected, including 53 (30.3\%) dog owners. The sociodemographic characteristics of the respondents are summarised in Table 1. Most respondents were Hindu (98.9\%), female $(56.0 \%)$, aged $\geq 29$ years old $(54.9 \%)$, with an educational background of higher secondary (28.6\%), residing in Songan A and B Village (86.9\%), working as farmers $(50.9 \%)$, with the level of income less than district minimum wage $(71.4 \%)$.
Table 1. Sociodemographic characteristics of the respondents $(n=175)$

\begin{tabular}{|c|c|}
\hline Variable/Category & $\mathbf{N}(\%)$ \\
\hline \multicolumn{2}{|l|}{ Gender } \\
\hline Male & $77(44.0)$ \\
\hline Female & $98(56.0)$ \\
\hline \multicolumn{2}{|l|}{ Age } \\
\hline Range (years) & $17-64$ \\
\hline Mean \pm SD (years) & $32.063 \pm 10.681$ \\
\hline$<29$ years & $79(45.1)$ \\
\hline$\geq 29$ years & $96(54.9)$ \\
\hline \multicolumn{2}{|l|}{ Residential village } \\
\hline Songan (A and B) & $152(86.9)$ \\
\hline Belandingan & $13(7.4)$ \\
\hline Pinggan & $10(5.7)$ \\
\hline \multicolumn{2}{|l|}{ Religion } \\
\hline Hinduism & 173 (98.9) \\
\hline Islam & $2(1.1)$ \\
\hline \multicolumn{2}{|l|}{ Educational background } \\
\hline No formal education & $19(10.9)$ \\
\hline Primary (1-6) & $37(21.1)$ \\
\hline Lower secondary (7-9) & $27(15.4)$ \\
\hline Higher secondary (10-12) & $50(28.6)$ \\
\hline Tertiary or higher & $42(24)$ \\
\hline \multicolumn{2}{|l|}{ Occupation } \\
\hline Not working & $28(16)$ \\
\hline Farmer & $89(50.9)$ \\
\hline Labourer & $2(1.1)$ \\
\hline Fisherman & $1(0.6)$ \\
\hline Entrepreneur & $19(10.9)$ \\
\hline White-collar worker & $18(10.3)$ \\
\hline Civil servant & $18(10.3)$ \\
\hline \multicolumn{2}{|l|}{ Level of income } \\
\hline$<$ District minimum wage & $125(71.4)$ \\
\hline$\geq$ District minimum wage & $50(28.6)$ \\
\hline
\end{tabular}

SD - standard deviation; the age groups were dichotomized at the median age, i.e., 29 years $(<29$ years of age and $\geq 29$ years of age)

\section{AWARENESS OF RABIES}

Most respondents (90.9\%) had heard of rabies through mass media (69 respondents, 43.4\%), non-mass media (51 respondents, $32.1 \%$ ), and a combination of both (39 respondents, $24.5 \%$ ). More than half of the respondents (64.3\%) had encountered rabid animals, and less than a fifth of the respondents (30 respondents, 17.1\%) had a history of animal bites. Nevertheless, not all respondents (15 re- 
Table 2. Respondents' knowledge, attitude and practice parameter of rabies

\begin{tabular}{|c|c|c|c|c|c|}
\hline \multicolumn{3}{|l|}{ Knowledge parameter } & \multicolumn{3}{|l|}{ Attitude and practice parameter } \\
\hline Variable & Correct & Incorrect & Variable & Agree & Disagree \\
\hline Definition of rabies & $162(92.6 \%)$ & $13(7.4 \%)$ & $\begin{array}{l}\text { Thinks vaccination as the initial mana- } \\
\text { gement after a dog bite }\end{array}$ & $73(41.7 \%)$ & $102(58.3 \%)$ \\
\hline $\begin{array}{l}\text { The major reservoir of rabies } \\
\text { is a rabid dog }\end{array}$ & $125(71.4 \%)$ & $50(28.6 \%)$ & $\begin{array}{l}\text { Thinks washing rabies wounds as } \\
\text { the initial management }\end{array}$ & $171(97.7 \%)$ & $4(2.3 \%)$ \\
\hline $\begin{array}{l}\text { Other possible reservoirs } \\
\text { of rabies (cat, monkey, and } \\
\text { bats) }\end{array}$ & $139(79.4 \%)$ & $36(20.6 \%)$ & $\begin{array}{l}\text { Thinks anti-septic application on the } \\
\text { wound as the second step after } \\
\text { wound washing }\end{array}$ & $139(79.4 \%)$ & $36(20.6 \%)$ \\
\hline Pathogenesis of rabies & $163(93.1 \%)$ & $12(6.9 \%)$ & $\begin{array}{l}\text { Thinks after wound washing, going } \\
\text { to the PHC/hospital to obtain PEP }\end{array}$ & $173(98.9 \%)$ & $2(1.1 \%)$ \\
\hline $\begin{array}{l}\text { Sign and symptoms of rabies } \\
\text { in a dog }\end{array}$ & $157(89.7 \%)$ & $18(10.3 \%)$ & $\begin{array}{l}\text { Thinks dog need to be chained or } \\
\text { caged to avoid rabies }\end{array}$ & $160(91.4 \%)$ & $15(8.6 \%)$ \\
\hline $\begin{array}{l}\text { Sign and symptoms of rabies } \\
\text { in human }\end{array}$ & $146(83.4 \%)$ & $29(16.6 \%)$ & $\begin{array}{l}\text { Thinks chained or caged dogs still } \\
\text { require vaccination }\end{array}$ & $169(96.6 \%)$ & $6(3.4 \%)$ \\
\hline $\begin{array}{l}\text { Initial management of a dog } \\
\text { bite }\end{array}$ & $72(41.1 \%)$ & $103(58.9 \%)$ & $\begin{array}{l}\text { Thinks vaccinated dogs does not } \\
\text { require special identification signage }\end{array}$ & $69(39.4 \%)$ & $106(60.6 \%)$ \\
\hline Infection risk of rabies & $162(92.6 \%)$ & $13(7.4 \%)$ & Thinks FRDs should be culled & $97(55.4 \%)$ & $78(44.6 \%)$ \\
\hline $\begin{array}{l}\text { Prevention through vaccina- } \\
\text { tion of both human and dogs }\end{array}$ & $23(13.1 \%)$ & $152(86.9 \%)$ & $\begin{array}{l}\text { Thinks a dog that has bitten several } \\
\text { people has to be observed }\end{array}$ & $170(97.1 \%)$ & $5(2.9 \%)$ \\
\hline $\begin{array}{l}\text { Culling as a method } \\
\text { of prevention for rabies } \\
\text { spread }\end{array}$ & $64(36.6 \%)$ & $111(63.4 \%)$ & $\begin{array}{l}\text { Thinks FRDs with abnormal behaviour } \\
\text { should be reported to local authorities } \\
\text { (health and livestock department) }\end{array}$ & $170(97.1 \%)$ & $5(2.9 \%)$ \\
\hline
\end{tabular}

FRDs - free-roaming dogs; PEP - post-exposure prophylaxis; PHC - public health centre

spondents, 8.6\%) were aware of rabies infection's fatality. Lastly, only approximately one-third of the respondents (75 respondents, 32.9\%) had heard of the local rules and regulations about dog and control of rabies. Of these, only $60 \%$ knew the rules and regulations.

\section{KNOWLEDGE, ATTITUDES AND PRACTICES REGARDING RABIES AND DOGS}

The median score for correct responses towards rabies knowledge; attitudes and practices towards rabies were 7 and 8 , respectively.

\section{KNOWLEDGE TOWARDS RABIES}

In general, the knowledge parameter of rabies was sufficient (Table 2). A large number of respondents answered correctly and identified dogs as the major host of rabies, followed by a similar proportion who knew other possible hosts of rabies (cat, monkey, and/or bat), as well as the pathogenesis of rabies, its sign and symptoms in both dog and human and infection risk of rabies. Nonetheless, their ignorance about the initial management, prevention through vaccination, and culling as a prevention method for the spread of rabies should be noted.

Statistically, the mean knowledge \pm standard deviation (range) score (out of ten) was $6.93 \pm 1.83(1-10)$. The score was significantly higher in females aged $<29$ years old with an educational background of secondary and above who have heard of rabies, encountered animals suspected of having rabies, with no previous history of animal bites, and were aware of rabies infection's fatality. The association between sociodemographic characteristics and awareness of rabies reflected by the respondents' knowledge is presented in Table 3.

\section{ATTITUDES AND PRACTICES TOWARDS RABIES}

In general, a large proportion of respondents disagreed that vaccination/PEP is the initial management after a dog bit and agreed that washing rabies wounds is the initial steps of management followed by anti-septic application on the wound and going to the PHC/hospital to obtain PEP. Nearly all respondents agreed that a dog needs to be chained or caged and that vaccination is compulsory to avoid rabies. Furthermore, observation and report to the local authorities should be made for an FRD dog showing abnormal behaviour.

Statistically, the mean attitudes and practices \pm \pm standard deviation (range) score (out of ten) was $8.04 \pm$ \pm 1.07 (4-10). A similar result was obtained in females with an educational background of secondary and above who has heard of rabies, met rabid animals, with no previous history of animal bites, and was aware of rabies infection's fatality. In contrast, respondents aged $\geq 29$ years old were showing more positive attitudes and practices towards rabies. The 


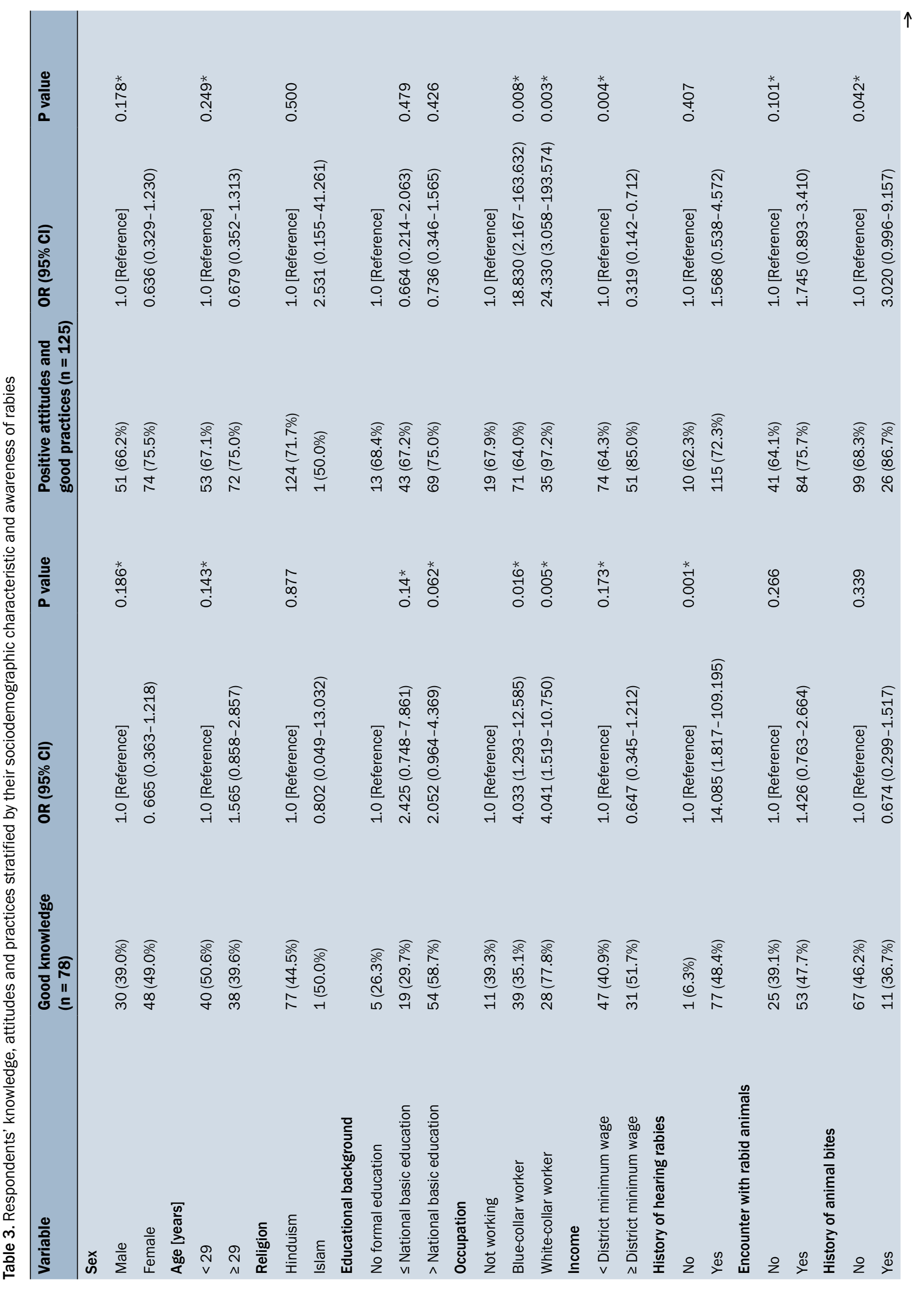




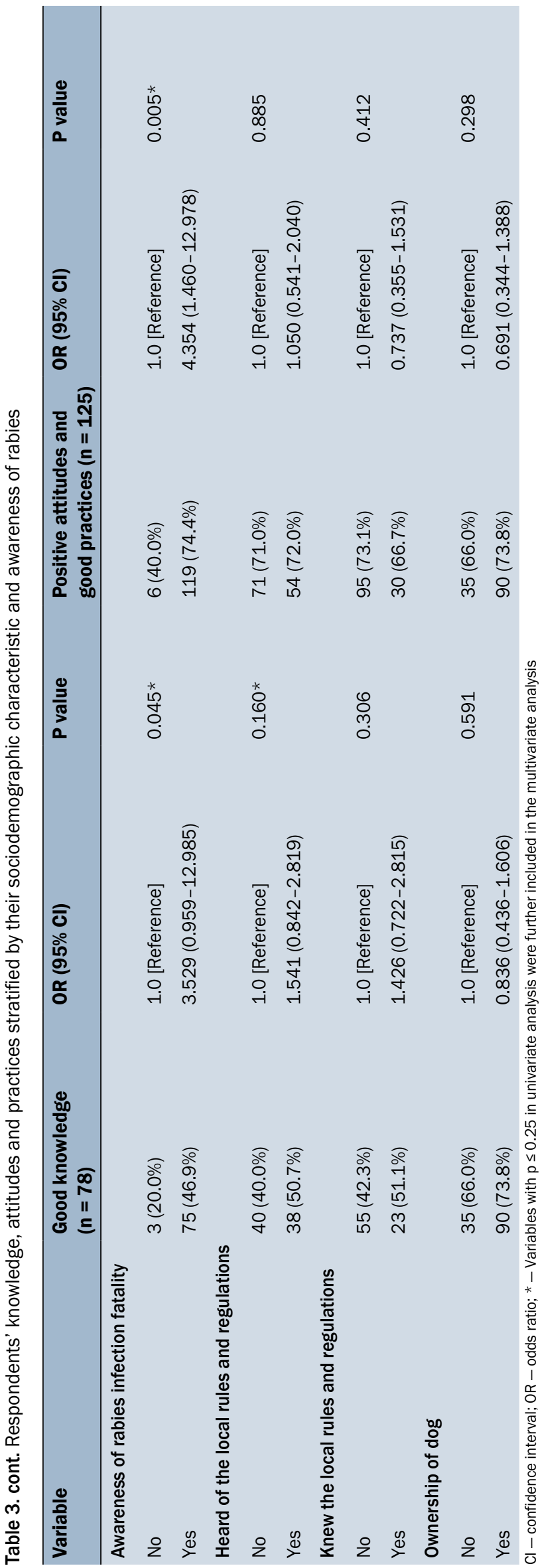

association between sociodemographic characteristics and awareness of rabies towards the respondents' attitudes and practices is presented in Table 3 .

\section{RESPONDENTS' ATTITUDES AND PRACTICES TOWARDS DOGS}

In general, most of the respondents in this study are non-dog owners (122 respondents, 69.7\%). The majority of the respondents $(70.9 \%)$ believed that dogs were kept as pets and a minority (5.7\%) agreed that dogs have economic value. A large proportion of the respondent (72.6\%) believed that dogs should be kept in a cage or chained in their land property, while $14.9 \%$ and $9.1 \%$ believed that dogs should be allowed to roam freely in and outside their land property, respectively. Nevertheless, 6 (3.4\%) respondents did not know how to pet a dog.

Out of the 53 dog owners, $46(86.8 \%)$ respondents regularly vaccinate the pet dog, $35(66.0 \%)$ respondents chained or built a special cage for the pet dog, yet $34(64.2 \%)$ respondents let the pet dog roamed freely. In terms of hygiene, 47 (88.7\%) respondents wash hands after contact with the pet dog. In terms of willingness to take action, the majority $(88.7 \%$ and $69.8 \%)$ of the respondents were willing to observe and cull the pet dog if the pet dog bites or show abnormal behaviour, respectively.

\section{KNOWLEDGE, ATTITUDES AND PRACTICES REGARDING RABIES}

In general, the majority of the respondent in this study have good knowledge, followed by positive attitudes and good practices regarding rabies ( 66 respondents, $37.7 \%$ ). However, $21.7 \%$ of the respondents have poor knowledge, negative attitudes, and poor practices regarding rabies. Association between respondents' knowledge and attitudes and practices has shown to be statistically significant $(P$-value $=0.001$ ) with an odds ratio (OR) (95\% Cl) of 3.542 (1.694-7.409).

\section{LOGISTIC REGRESSION ANALYSIS}

The analysis between the respondents' characteristics and rabies awareness with outcome variables is presented in Table 4. The results showed that each of the factors considered in this study had a p-value $\leq 0.25$ for at least one of the outcome variables. This study's multivariate logistic regression analysis revealed that occupation had a statistically significant association with knowledge and attitudes and practice regarding rabies, while the history of hearing about rabies had a statistically significant association with knowledge regarding rabies.

\section{DISCUSSION}

This present study was developed and undertaken to assess the KAP of the community member in Songan Village to 
Table 4. Multivariable logistic regression analysis of factors of knowledge, attitudes and practices regarding rabies

\begin{tabular}{|c|c|c|c|c|}
\hline \multirow[t]{2}{*}{ Variable } & \multicolumn{2}{|l|}{ Adequate knowledge } & \multicolumn{2}{|c|}{ Positive attitude and practices } \\
\hline & OR (95\% Cl) & P-value & OR (95\% Cl) & P-value \\
\hline \multicolumn{5}{|l|}{ Sex } \\
\hline Male & $1.0[$ Reference] & 0.459 & - & - \\
\hline Female & $1.302(0.647-2.619)$ & & & \\
\hline \multicolumn{5}{|l|}{ Age } \\
\hline$<29$ years & $1.0[$ Reference $]$ & 0.235 & $1.0[$ Reference] & 0.229 \\
\hline$\geq 29$ years & $0.636(0.301-1.343)$ & & $1.636(0.733-3.648)$ & \\
\hline \multicolumn{5}{|l|}{ Educational background } \\
\hline No formal education & $1.0[$ Reference] & & $1.0[$ Reference $]$ & \\
\hline$\leq$ National basic education & $1.097(0.281-4.289)$ & 0.894 & $0.578(0.159-2.103)$ & 0.405 \\
\hline > National basic education & $1.870(0.827-4.227)$ & 0.133 & $0.753(0.327-1.733)$ & 0.505 \\
\hline \multicolumn{5}{|l|}{ Occupation } \\
\hline Not working & $1.0[$ Reference] & & $1.0[$ Reference] & \\
\hline Blue-collar worker & $5.864(1.479-23.258)$ & 0.012 & $12.068(1.253-116.199)$ & 0.031 \\
\hline White-collar worker & $4.053(1.382-11.884)$ & 0.011 & $20.146(2.435-166.692)$ & 0.005 \\
\hline \multicolumn{5}{|l|}{ Income } \\
\hline$<$ District minimum wage & $1.0[$ Reference] & 0.422 & $1.0[$ Reference] & 0.236 \\
\hline$\geq$ District minimum wage & $0.716(0.317-1.617)$ & & $1.760(0.691-4.482)$ & \\
\hline \multicolumn{5}{|l|}{ History of hearing rabies } \\
\hline No & $1.0[$ Reference] & 0.04 & - & - \\
\hline Yes & $0.099(0.011-0.902)$ & & & \\
\hline \multicolumn{5}{|l|}{ Encounter with rabid animals } \\
\hline No & $1.0[$ Reference] & 0.809 & $1.0[$ Reference] & 0.293 \\
\hline Yes & $0.914(0.441-1.894)$ & & $0.663(0.309-1.425)$ & \\
\hline \multicolumn{5}{|l|}{ History of animal bites } \\
\hline No & $1.0[$ Reference] & 0.354 & $1.0[$ Reference] & 0.080 \\
\hline Yes & $1.592(0.596-4.252)$ & & $0.345(0.105-1.134)$ & \\
\hline \multicolumn{5}{|c|}{ Awareness of rabies infection fatality } \\
\hline No & $1.0[$ Reference $]$ & 0.199 & $1.0[$ Reference] & 0.128 \\
\hline Yes & $0.377(0.085-1.672)$ & & $0.390(0.116-1.313)$ & \\
\hline \multicolumn{5}{|c|}{ Heard of the local rules and regulation } \\
\hline No & $1.0[$ Reference] & 0.632 & $1.0[$ Reference] & 0.636 \\
\hline Yes & $1.189(0.586-2.411)$ & & $1.203(0.560-2.584)$ & \\
\hline \multicolumn{5}{|l|}{ Hosmer and Lemeshow Test } \\
\hline Chi-square & 4.591 & & 4.065 & \\
\hline Sig. & 0.800 & & 0.851 & \\
\hline
\end{tabular}

$\mathrm{Cl}$ - confidence interval; $\mathrm{OR}$ - odds ratio

understand further the challenges faced in Bali in the objective to reduce the incidence of dog-bite rabies. Although few studies have identified a lack of awareness in parts of Bali province, this is the first study that relates the KAP towards rabies of community members in Songan Village. Our findings highlight the factors contributing to rabies' knowledge, attitudes and practices across Songan Village that could be targeted to improve health-seeking behaviour and rabies control practices.

Bali province has an area of $5,632 \mathrm{~km}^{2}$ with nine districts, namely, Jembrana, Tabanan, Badung, Gianyar, Ka- 
rangasem, Klungkung, Bangli, Buleleng, and Denpasar city. Rabies was first detected in Bali Province in 2008. Ever since, there was a shift from the centre of case findings in Badung District towards the peripheral, including Bangli District. From 2008 to 2018 in Bali, 174 death cases due to rabies and 1.838 rabies-positive dogs have been reported. In 2009, the first recorded case of rabies in Bangli District was reported in Bebalang Village, followed by 2010, with the highest reported positive rabies cases in Bangli District constituting 51 cases. In Bangli district from 2008 to 2015, 7 death cases due to rabies and 289 positive dog rabies have been reported $[6,10]$.

Of the 175 community members surveyed, the majority were female (56.0\%) in contrast to studies in India and Grenada $[2,11]$. The median age of the respondents was 29 years, ranging from 17 to 64 years, similar to a study in East Nusa Tenggara Province, Indonesia with a median of 34 and range from 19 to 73 years of age [12]. Our results indicated that the community members' younger population had a higher rate of good knowledge about rabies. This may be associated with the educational background among young people in whom the high level of education probably translated into higher knowledge of rabies compared to adults. This finding is in line with previous studies $[13,14]$. Nevertheless, none of the associations between sex, age group classification, and educational background were statistically significant in our study.

Almost all of the respondents (98.9\%) were Hindu. The relation between Hinduism, Bali and dogs is explained in a spiritual relation from the Tri Hita Karana's philosophy as well as a sociocultural study carried out in Bali [15]. From a socioeconomic perspective, Bangli District, specifically Sukawana Village, is a well-known conservation area for Kintamani dogs [16].

Our study further revealed that district minimum wage influenced attitudes and practices of rabies. A plausible explanation is related to the socioeconomic status in which the respondents with higher socioeconomic status were more likely to comply to the correct initial management, seek treatment in the PHC/hospital, vaccination among FRDs, correctly identified measures restricting FRD population, and alert the local authorities of the presence of an FRD with abnormal behaviour as seen in another study in India. As expected from other studies, better knowledge about the disease should translate into the adoption of better practices, which is supported by this study showing significant associations between respondents with good knowledge and positive attitudes and good practices regarding rabies (OR $3.542,95 \% \mathrm{Cl} 1.694-7.409$, and p-value $=0.001)[17,18]$.

Rabies awareness assessment showed that $90.9 \%$ has heard about rabies, which is similar to a study in Morocco, India, and Ethiopia [14, 19, 20]. The majority has heard about rabies from mass media (43.4\%), consistent with a study in Sukabumi, a province in West Java, Indonesia, and more than half of the community members had met animals suspected of having rabies [21]. This suggested that the community members were aware of rabies' presence in their area, which could be attributed to the prioritising of the disease by the Provincial Government of Bali. Nevertheless, only a small proportion of the community members have heard of the local rules and regulation about dogs and rabies' control. These findings suggested $r$ advocacy for further informing about rules and regulations regarding rabies for a better comprehensive understanding of rabies in the community.

After excluding insignificant predictor factors from the analysis, the multivariate model revealed that occupation was the only independent factor of knowledge, attitudes and practices regarding rabies (Table 4). In the final model, there were increased odds of having good knowledge and positive attitudes and good practices among participants who were classified as white-collar workers compared to not working (OR 4.053 and $20.146,95 \% \mathrm{Cl} 1.382-11.884$ and $2.435-$ -166.692 , and $p$-value $=0.011$ and 0.005 , respectively) as well as blue-collar workers compared to not working (OR 5.864 and $12.068,95 \% \mathrm{Cl} 1.479-23.258$ and $1.253-$ -116.199 , and $p$-value $=0.012$ and 0.031 , respectively). Occupations were found to influence good knowledge, positive attitude and good practices significantly. A potential explanation might be related to the time allocation comparatively between white-collar workers and blue-collar workers, in which blue-collar workers have to work every day whereas white-collar workers have a holiday within the weekend. The discrepancy between the available times could lead as the main reason for less knowledge and the less translation of knowledge into positive attitudes and good practices for groups other than white-collar workers [20, 22, 23].

Most of the respondents (97.7\%) correctly identified washing a wound from a suspected rabid dog as the initial step. Washing the bite wound with water and soap is a pivotal component of PEP; lack of wound washing has shown to be responsible for a five-fold increase in the risk of developing rabies [24, 25]. This fundamental result was in contrast with a study in Bali in which due to widespread local belief (prior to the rabies outbreak) that dog licks could heal wounds and this belief led to the practice of not washing wounds, including bite wounds. Almost all of the respondents (98.9\%) believed that visiting a local $\mathrm{PHC} /$ hospital was necessary after a suspected rabid dog bite and that vaccination (PEP) should be sought, as reported in a similar study. A probable explanation is that respondents wrongly believed that in the $\mathrm{PHC} /$ hospital there was a medicine to treat rabies and a minority understood that vaccinations could only block the virus transmission and was not the same as medicine [15]. 
Majority of the respondents (63.4\%) incorrectly identified culling as a prevention method for the spread of rabies followed by $55.4 \%$ who agreed that FRD should be culled. Culling is an ineffective method for controlling rabies. For instance, in response to a rabies outbreak in 1997, in Flores, Indonesia, nearly half of the dog populations were culled. Nevertheless, in 2004, although the total dog population was still considerably reduced, rabies was still endemic [26]. Similar failure reports of culling were also reported from Korea, while subsequent vaccination yielded a controlled disease [27]. In order to specifically interrupt the animal-human transmission cycle of rabies, mass vaccination of dogs is essential. According to the WHO, at least $70 \%$ vaccination coverage of the canine population should be reached in order to break this cycle. This further complemented the need of higher awareness among community members, specifically dog owners, about the importance of dog vaccination [14, 28].

In the highlight of this study, the significant difference between knowledge and attitudes and practices may be related to current public educational programmes that are mainly focused on prevention, vaccination, and initial management after exposure to an animal bite. Low media involvement of clinical manifestation of rabies in man and animal may have negatively impacted in this regard [29]. Therefore, appropriate programmes should be designed to increase the knowledge of the community in faith to subsequently improve the translation into positive attitudes and good practices regarding rabies.

The fight against rabies in Indonesia, in particular Bali, is on the right track. The Provincial Government of Bali has made several attempts to control rabies incidence through the implementation of local rules and regulations, annual mass dog vaccination, and selective dog elimination. Nevertheless, it has not been optimal because the cases of rabies are still present. Several gap analysis has been published reporting and further strengthening the One Health approach that is essential: 1) a good continuing surveillance system will benefit the approach as it can portray the real situation of the number of dogs vaccinated, FRDs, and unvaccinated dogs, 2) scheduled mass vaccination system with community engagement, risk area mapping, and case estimation, 3 ) educating the community members and visiting tourists of preventive measures towards every dog bite cases, 4) the importance of dog vaccination and schedule should be informed to family, schools, and communities, and 5) integrated, continuous, and collaborative measures among stakeholders should be reinforced [30].

Inevitably, there were some limitations of the present study. First, this study could not determine how all the reported practices were translated into actual practice. Second, this study only provided the primary data on KAP regarding rabies, particularly in Songan Village and may not be generalized to other parts in Bali. Lastly, the survey did not address all the questions related to KAP. To our best knowledge, this is the first study to report KAP regarding rabies in the Songan Village, Bangli District, Bali, Indonesia.

\section{CONCLUSIONS}

Albeit community members demonstrated some level of KAP regarding rabies, overall, this study revealed critical gaps in their fundamental knowledge of rabies, the prevention in dogs, and the local rules and regulations concerning rabies. In accordance with the One Health approach, further enforcement on the collaborative efforts for comprehensive education programmes, scheduled mass vaccination for dogs, and promotion for healthier attitudes and practices are recommended.

\section{ACKNOWLEDGEMENTS}

The authors thank all the community members who gave their time and effort in participating in this study. We also would like to acknowledge the Public Health Centre of Kintamani V, the district government of Bangli, and the provincial government of Bali for allowing us to conduct the study.

\section{CONFLICT OF INTEREST}

The authors declare no conflicts of interest.

\section{REFERENCES}

1. Murray P, Rosenthal K, Pfaller M. Rhabdoviruses, filoviruses, and bornaviruses. In: Medical Microbiology. 8th ed. Elsevier, Philadelphia 2013: 496-500.

2. Tiwari HK, Robertson ID, O'Dea M, et al. Knowledge, attitudes and practices (KAP) towards rabies and free roaming dogs (FRD) in Panchkula district of north India: A cross-sectional study of urban residents. PLoS NegI Trop Dis. 2019; 13(4): e0007384, doi: 10.1371/journal. pntd.0007384, indexed in Pubmed: 31034474.

3. Gongal G, Wright AE. Human rabies in the WHO Southeast Asia region: forward steps for elimination. Adv Prev Med. 2011; 2011: 383870, doi: 10.4061/2011/383870, indexed in Pubmed: 21991437.

4. Ministry of Health of the Republic of Indonesia. Buku saku petunjuk teknis penatalaksanaan kasus gigitan hewan penular rabies di Indonesia. Jakarta: Kementerian Kesehatan RI. 2016.

5. Ministry of Health of the Republic of Indonesia. Profil Kesehatan Indonesia Tahun 2019. Jakarta: Kementerian Kesehatan RI. 2020.

6. Nugroho DK, Diarmitha IK, Tum S, et al. Analysis of rabies surveillance data (2008-2011) in Bali Province, Indonesia. OSIR. 2013; 6(2): 8-12.

7. Manro NM, Yovani N. Towards a rabies-free Indonesia by 2020 : Institution problem of public health policy implementation in Bali. J Kebijak Kesehat Indones. 2018; 7(4): 168-177.

8. Bartlett EJ, Kotrlik WJ, Higgins CC. Organization Research: Determining appropriate sample size in survey research. Info Tech Lear Perform J. 2001; 19(1): 43-50.

9. Noah N. The STROBE initiative: STrengthening the Reporting of OBservational studies in Epidemiology (STROBE). Epidemiol Infect. 2008; 136(7): 865, doi: 10.1017/S0950268808000733, indexed in Pubmed: 18482461. 
10. Santhia K. Human rabies epidemiology in Bali, Indonesia. Int J Health Med Sci. 2019; 2(1): 7-16, doi: 10.31295/ijhms.v2n1.77.

11. Glasgow L, Worme A, Keku E, et al. Knowledge, attitudes, and practices regarding rabies in Grenada. PLoS NegI Trop Dis. 2019; 13(1): e0007079, doi: 10.1371/journal.pntd.0007079, indexed in Pubmed: 30695024.

12. Hoetama E, Tanri N, Gianni L, et al. Pengetahuan, Sikap, dan Perilaku Masyarakat terhadap Penyakit Rabies di Kabupaten Manggarai, Nusa Tenggara Timur, 2014. eJKI. 2017; 4(3), doi: 10.23886/ ejki.4.7111.177-82.

13. Awuni B, Tarkang E, Manu E, et al. Dog owners' knowledge about rabies and other factors that influence canine anti-rabies vaccination in the Upper East region of Ghana. Trop Med Infect Dis. 2019; 4(3): 1-13, doi: 10.3390/tropicalmed4030115, indexed in Pubmed: 31426558.

14. Bouaddi K, Bitar A, Bouslikhane M, et al. Knowledge, attitudes, and practices regarding rabies in El Jadida region, Morocco. Vet Sci. 2020; 7(1): 1-12, doi: 10.3390/vetsci7010029, indexed in Pubmed: 32121594.

15. Widyastuti MD, Bardosh KL, Basri C, et al. On dogs, people, and a rabies epidemic: results from a sociocultural study in Bali, Indonesia. Infect Dis Poverty. 2015; 4: 30, doi: 10.1186/s40249-0150061-1, indexed in Pubmed: 26137295.

16. Andriani F, Batan IW, Kardena IM. The correlation analysis and spreading pattern of rabies cases between dogs and human in Bangli from 2009-2014. Indones Med Veterinus. 2016; 5(1): 79-88.

17. Harapan H, Rajamoorthy Y, Anwar S, et al. Knowledge, attitude, and practice regarding dengue virus infection among inhabitants of Aceh, Indonesia: a cross-sectional study. BMC Infect Dis. 2018; 18(1): 96, doi: 10.1186/s12879-018-3006-z, indexed in Pubmed: 29486714.

18. Ntampaka P, Nyaga PN, Niragire F, et al. Knowledge, attitudes and practices regarding rabies and its control among dog owners in Kigali city, Rwanda. PLoS One. 2019; 14(8): e0210044, doi: 10.1371/ journal.pone.0210044, indexed in Pubmed: 31430285.

19. Sarjana N, Prasetyawati A, Budiani D. Hubungan antara Tingkat Pengetahuan dan Sikap dengan Tindakan Pencegahan Penyakit Rabies pada Warga di Wilayah Puskesmas Kuta II. Smart Med J. 2018; 1(1): 18, doi: 10.13057/smj.v1i1.24184.

20. Tiwari HK, O'Dea M, Robertson ID, et al. Knowledge, attitudes and practices (KAP) towards rabies and free-roaming dogs (FRD) in Shirsuphal village in western India: A community based cross-sectional study. PLoS Negl Trop Dis. 2019; 13(1): e0007120, doi: 10.1371/ journal.pntd.0007120, indexed in Pubmed: 30682015.

21. Hagos WG, Muchie KF, Gebru GG, et al. Assessment of knowledge, attitude and practice towards rabies and associated factors among household heads in Mekelle city, Ethiopia. BMC Public Health. 2020; 20(1): 57, doi: 10.1186/s12889-020-8145-7, indexed in Pubmed: 31937297.

22. Wicaksono A, llyas AZ, Sudarnika E, et al. Knowledge, attitude, and practice study of dog owners related to rabies in Sukabumi District, West Java. JVeteriner. 2018; 19(2): 230-41, doi: 10.19087/j. veteriner.2018.19.2.230.

23. Ameh VO, Dzikwi AA, Umoh JU. Assessment of knowledge, attitude and practice of dog owners to canine rabies in Wukari metropolis, Taraba State, Nigeria. Glob J Health Sci. 2014; 6(5): 226-240, doi: 10.5539/gjhs.v6n5p226, indexed in Pubmed: 25168987.

24. Sambo M, Lembo T, Cleaveland S, et al. Knowledge, attitudes and practices (KAP) about rabies prevention and control: a community survey in Tanzania. PLoS Negl Trop Dis. 2014; 8(12): e3310, doi: 10.1371/journal.pntd.0003310, indexed in Pubmed: 25473834.

25. Hampson K, Dobson A, Kaare M, et al. Rabies exposures, post-exposure prophylaxis and deaths in a region of endemic canine rabies. PLoS Negl Trop Dis. 2008; 2(11): e339, doi: 10.1371/journal. pntd.0000339, indexed in Pubmed: 19030223.

26. Morters MK, Restif $\mathrm{O}$, Hampson K, et al. Evidence-based control of canine rabies: a critical review of population density reduction. J Anim Ecol. 2013; 82(1): 6-14, doi: 10.1111/j.1365-2656.2012.02033.x, indexed in Pubmed: 23004351.

27. Lee JH, Lee MJ, Lee JB, et al. Review of canine rabies prevalence under two different vaccination programmes in Korea. Vet Rec. 2001; 148(16): 511-512, doi: 10.1136/vr.148.16.511, indexed in Pubmed: 11345995.

28. Batan IW, Suatha IK. actors encouraging the incidence of rabies in dogs in villages in Bali. J Vet. 2016; 17(2): 274-279, doi: 10.19087/ jveteriner.2016.17.2.274.

29. Bagherian HR, Taghipour A, Nezamdoost F, et al. Knowledge, attitude and practices regarding animal bites and rabies; A multi-centre study. Asia Pac J Med Toxicol. 2018; 7(4): 92-95, doi: 10.22038/ APJMT.2018.11980.

30. Subrata M, Purnama SG, Utami A, et al. Role of stakeholder in rabies control with integrated One Health approach in Bali. J Kebijak Kesehat Indones. 2020; 09(01): 20-32. 